\title{
Isolator Device
}

National Cancer Institute

\section{Source}

National Cancer Institute. Isolator Device. NCI Thesaurus. Code C50011.

Any material or structure designed to limit the interaction between two components. 